\title{
İnsanın Temel Ödevlerine Toplu Bir Bakış*
}

\author{
O. LEMARIÉ \\ Tercüme: MURTAZA KORLAELÇİ \\ Prof.Dr., ANKARA Ü. İLAHIYAT FAKÜLTESI
}

İnsan için görevin, "şahıslarla" ilişkilerinden doğan mecburiyet olduğunu söyledik. (Kendinde onları sayg1 değer k1lan herhangi bir değere sahip olan varlıklar) şahıslar hangileridir? Bunların, belli bir derecede Hayata katılan bütün varlıklar olduğu şeklinde cevap vereceğiz: İlkin bu hususta ortak ve esrarlı kaynak olan Tanrı, sonra dünyevî üretim (dérivation) olan insanlık ve az bir derecede hayvanlık (animalité).

Ödevlerimizi sıralamak, bizim için bu üç canlı realiteye bağlı olarak, kendi durumumuzdan doğan mecburiyetlerin hangileri olduğunu belirtmektir. Böylece üç başlık elde ediyoruz:

1- Tanrı’ya karşı ödevlerimiz; 2- İnsana karşı ödevlerimiz; 3- Hayvana karş1 ödevlerimiz.

\section{I- TANRIYA KARŞI ÖDEVLERIMIZ}

Tanrı'nın, insan hayalinden doğmuş bir hayalet olduğuna inanmış olan bir kimse için, öyle görünüyor ki ödevin birinci sınıfı kaldırılmış olacaktır. Var olmadığına inanılan bir şey hakkında neden sorumlu olunabilir? $\mathrm{O}$ halde ateist (athée), dindarlığı tanımıyor. Ona göre bu mantıklıdır. Fakat o zaman, varlığın diğer kalan tümü için ödevleri reddetmek gerekir; zira eğer Tanrı yoksa hiçbir

* Yapılan bu çeviri, O.Lemarié'nin Esquisse d'une philosophie, Paris 1927 isimli eserinde ss.474-489 yer almaktadır. 
şey kutsal değildir. $\mathrm{O}$ zaman insanın bizzat kendisi, maddenin diğer herhangi bir parçası gibi, kendiliğinden hiçbir değere sahip olmayacaktır. Gerçek ateist, ahlâkın kutsal özelliğine inanamaz. Ona göre mecburiyet sadece ortaklaşa güç üzerine kurulabilir; eğer mecburiyet, rahatlığın (aisance) üretici ve koruyucusu olarak değerlendirilirse, bir (iç veya dış) baskı olarak kabul edilebilir ancak. Mecburiyeti reddetmek bir hata değil, fakat bir beceriksizlik, yani bir alçalmadır. Fakat böyle bir ateist var mı? Ateist isimi verilen herkes, taştan daha fazla değere sahip olmayı, kendilerine saygı gösterilmesine layık olmayı, ve Tanrı'yı tamamen reddettikleri halde, soylulaşma ilkesi olarak ödevi muhafaza etmeyi (maintenir) iddia etmiyorlar mı? Bu konuda onlar aldanıyorlar. Onlar, itiraf etmeksizin, delilsiz olarak, insanı ilahlaştırdılar; çünkü saygının heyecanı ve bir bağımlılık duygusu, Hayatın içinde ispat edilirse, kutsal bir Gerçeğin hazır oluşu ve eylemi yine Hayatın içinde fark edilirse ancak ödeve inanılır.

Fakat burada insan oldukça karmaşı bir kavramla nasıl yetinecektir? (İnsan hayatı Tanrı'nın var veya yok oluşuna göre tamamen farklı bir anlam aldığı için) O’nun özel varoluşunun temel probleminin iç yüzünü görmek, düşünecek her insanın temel çabasıdır. Bunun için diyoruz ki Tanrı'ya karşı ilk ödev, O'nu araştırmaktır.

O zaman, O'nun hakkında elde ettiğimiz bilgi, O'na karşı davranışımızı bize dikte ettirir. Bundan böyle, nedensiz bir araz olarak değil, bir lütuf olarak bize görünen hayatımız artık sadece şükranın devamlı bir fiili olabilecektir. Onu bir kelime özetleyecektir: bir evladın ana- baba sevgisi.

$\mathrm{Bu}$ sevgi nasıl ifade edilecektir? $\mathrm{Bu}$, Tanrı bizim yokluğumuzdan ıstırap çekiyormuş gibi, O'na bizim temin edeceğimiz bir yardım, bir hafifletme olamaz. Bizim sevgimiz (amour), bizim çabamızı isteyen ilâhî tasarılarda sadece tam ve samimi bir işbirliği olabilir. Tanrı'yı sevmek, O’nun eserinde hizmet etmektir; o halde bu onlarda Tanrı'nın iradesini görerek kendi özel ödevlerinin tümünü gerçekleştirmektir. Dindar olmak yaşayanlar arasında, günlük ödevlerini, işinin değer ve anlamını bilmeyen makine gibi değil, sadece ücretini düşünen ücretli gibi olmayan, asaletle Babanın düşüncesine giren bilgili oğul gibi, samimi olarak gerçekleştirmektir.*

* Bu ifadeler Hristiyanlık dini için söz konusu olabilir. İslâm dininde insanlar Allah'ın kuludur. O'nun emir ve yasaklarını uygulamak, her mü’minin ilk ödevidir. (çev. notu) 


\section{II- İNSANA KARŞI ÖDEVLERIMIZ}

İnsan Şahsiyetinin Değeri: İnsan, insan için dokunulamaz bir gerçektir. Hangi nedenlerle? Onu yeniden söylüyoruz: Eğer insan ögelerinin (rastlantı sonucu veya zorunlu) karşılaşması ile günün birinde (un beau jour) doğarsa, bu insan hiçbir şeye sahip olamayacaktır ve insan şahsının her tapınışı aldatmaca olacaktır. Eğer insanı üreten kaynak kutsal ise, yani eğer, insanın ürünü olduğu Yaratılış (Nature) kendinden bir değere sahipse insan ancak kutsal olur. Herhangi bir varlığın saygıdeğer olması için, aziz bir Gerçekliğin Tabiatından fişkırması gerekir; ve bu varlık Yaratanı ile daha sıkı iletişime girdiği ölçüde var olacaktır. Eğer insan bizim için bir saygı objesi ise, bu Tabiatın kalıntısından ziyade, Tanrı ile ilişkisinin daha içten olmasındandır.

O halde insanın değeri türetilmiştir (dérivé). Bu "kendi başına" (par soi) değildir, o kutsaldır ama Tanrı'nın istediği kadar, Tanrı tarafından sevildiği kadar ve Tanrı tarafından verilmiş (assigné) ödeve (tâche) davet edildiği kadar kutsaldır. Eğer bizden her birimiz için insan, eylemin amacı olsa bile, o bir en son amaç değildir; zira Tanrı' dan gelmiş olmasına rağmen insan, yine de Tanrı değildir. İnsanlığın her dini bu ana ihtiyatı ister.

Fakat o halde insan niçin kutsaldır?

-İlkin o, Tanrı'nın eseri olduğu için (ve bu bütünüyle tabiatın olgusudur).

-İkinci olarak insan yerin şaheseri, Tanrı tarafından yön verilen sonsuz bir çabanın amacıdır. Böylece insan, bizzat Tanrı'nın fevkalade bir değer verdiği, ve diğerlerinden daha fazla samimi olarak birleşmeyi istediği bir yaratık gibi görünüyor. İnsan sadece Tanrı'nın eseri olarak hissedilmiyor, fakat O’nun imtiyazlı yaratığı, O’nun "çocuğu”* olarak hissediliyor.

-İnsan, Tanrı ile birlikte çalışmaya davet edildiği için saygı değerdir; zira onun "ödevinin" anlamı buradadır. Yaratılışın son amacı olan evrensel saadete, insan çok küçük çabasıyla onu oluşturmak için katkıda bulunması gerekiyor. Kutsal bir görevle yükümlü olduğu için o, kutsallaşır. Ahlâkî yasa, kendinin saygının ve tapınmanın objesi kılan bir özelliğe davet eden baskı yapar.

O halde insanda iki değer ayırt etmek uygundur: Kendi kaynağına ve kendi yeteneğine (vocation) benzeyen (hayatı kadar devam edecek olan) değer, ve kendi özel değeri (mérite) olacak olan değer. Yeni doğmuş, ahlâka yeteneksiz

* İnsan Allah'ın kuludur; Allah'ın çocuğu olamaz ve öylede hissedilemez. Bu düşünce teslisten kaynaklanan yanlış bir düşüncedir. (çev. notu) 
bir çocuk saygı hakkına sahiptir, çünkü o, aziz esere yönetilmiştir. Ödeve yan çizen, fakat ona daha az bağlı kalmayan suçlu, sabırlı Ustanın tekrar işe çağırdığı haylaz işçi olarak incelenmelidir. Bir anlamda onların değeri şartlıdır: Çocuk ve suçlu sadece görevlerini gerçekleştirdikleri ölçüde şahıs olarak değerli olacaktır; fakat onların yaptıkları rol, onlara saygı göstermeyi ve onlara yardım etmeyi emrediyor. Bu, onları asil kılan alın yazılarıdır.

Yine bundan şu sonuç çıkar: İnsanın kendi değerine değer biçmesi gerektiği yer kendi özel şahsiyetidir. Olaylar arasında papazlık yüklendiği zaman o, kendini olay halinde inceleyebilecektir. Tabiatta, yatıştırıcılığın (en küçük) rolünü oynamaya davet edildiği zaman o, orada kaçınmak hakkına sahip değildir. “Tanrı'ya dönüşün” alçak gönüllü işçisi, yumuşak ve uyumlu alet halinde işe kendini verecektir. Bu onun kendinde taşıdığı, her birimiz içinde görevlere sahip olduğu insan şahsı içindir. Kendi öz insanlığına hiçbir değer vermeyen kimse, başkasınınkini de tanımayacaktır.

\section{A- BİZZAT KENDİMIZZE KARŞI ÖDEVLERIMIIZ}

İnsanın bizzat kendine karşı ödevinin ilki, kendi öz asilliğinin şuurunda olmaktır. Kendi düşüncesinin temel kullanımı ancak, kendi alın yazısını araştırmak ve onu gerçekleştirmek için zorunlu olan kendisinin bilgisini araştırmakla mümkün olabilir. Bu durum, insanın amacını gerçekleştirmeye kendini elverişli kılacaksa ve kendine saygılı olacaksa, kendi varlığının saygınlığına çok iyi nüfuz ederse ancak vardır.

$\mathrm{Bu}$ kendine derin saygı beş ana maddeye bölünebilir: Hayatla, vücutla, zekâyla, karakterle, şerefle ilgili ödevler.

a- İnsanın Öz Kendi Hayatıyla İlgili Ödevler: İnsanın kendi hayatına karşı ilk ödevi, onu asla ne kesmek ne de kısaltmaktır. İntihar bir dönekliktir, tahsis edilmiş görevden bütünüyle vazgeçmektir. Hayat ne kadar güç olursa olsun, bizden kaldırılması bize ait olmayan bir görev olarak, tabii sonuna kadar ona tahammül etmeye mecburuz. Oyun veya şarlatanlıkla onu tehlikeye atmak aynı zamanda cinayettir. Onu tesadüfe terk eden, güç numaralar ve ustalıkla onu aptalca pratik olarak açıklamak ondaki önemli değeri inkâr etmek değil midir? Kazanılması beklenen şeyde bahse girmek, onun yapıldığı hali biraz belirtmektir.

Bununla beraber bu, Hayatın En Yüce İyi olması, ve onun üstüne hiçbir şey koymamakta yanılmasıdır. Hayat insanın en son amacı değildir, ama ödevinin 
şartıdır. Eğer kendini ona kıskançça kaptırmışsa, hayata bağlanmamak da gerekir. Ölümden daha kötü alçalmalar vardır, ve görevler yüce ve zorunlu oldukça insanın kendini onlara feda etmekte tereddüt etmemesi gerekir. Böylece doğru (Juste) bir neden için ölmek, (görevden kaçan insanın fiili) olan intihar değildir; tam aksine bu, bütün varlığını ödeve en üstün bir şekilde adamadır.

Nihayet hayatımız karşısında, onu asla israf etmemek, ve asla onu işsiz bırakmamak zorundayız. Ona sorumlu olduğumuz mülk (bien) gibi dikkat edeceğiz. Hayattan tam verim isteyelim: Zamanımızın cimrisi olalım. Yeryüzünde hiçbir şey yararsız olarak geçip gitmez, fakat becerikli ve cesaretli çalışan gerek. İşsiz yaşamak, yaşamanın değerini yitirmektir.

b- İnsanın Kendi Öz Bedeniyle İlgili Ödevler: Bir ahlâkî varlığın geçici örtüsü (re vêtement) ve onun çalışmasının geçici aleti olan vücudumuz, başkası tarafından olduğu kadar kendimiz tarafından da saygıyı hak eden, tesadüfen yüceltilmiş bir maddedir. Bu şekildeki ifade, onu kötüye kullanmak, kullanıminı saptırmak, onu bozmak veya onu toplu alay konusu yapmak olacaktır. - Görevimizin (tâche) âleti ve hayatın aktarıcısı olan vücudumuzu, sağlıklı bilgi ve egzersizle kuvvetlendirmiş olmak mecburiyetindeyiz. Bu, onun bütünlügünü ve gücünü, bir işçinin aletlerinin iyi halini koruduğu gibi korumak ödevidir. Hayatta başarmanın şartı kuvvetli olmaktır (un bonanimal).

Fakat hayat olmaksızın beden bir amaç olarak düşünülemeyecektir. Şüphesiz onu geliştirelim; ama son amacımız, hızın veya kasla ilgili yararsız mucizelerini (prodiges) bizzat kendimize amaç yapmak olmasın. Vücudun sağlığının şartı olan temizliği devam ettirelim; hatta başkalarına onu hoş görünümlü kılan çekiciliğini koruyalım; fakat onu süslemek ve sanat eseri haline dönüştürmek en yüce tutkumuz olmasın. - Aynı şekilde onun meşru istekleriyle yetinelim; fakat yapay hiçbir ihtiyacı yaratmayalım. Fizikî külfetlerimizi en aza indirelim.

Nihayet tamamıla uysal bir alet olarak elimizde kalması için vücudumuzu bilge disipline bağlayalım. Akla uygun "çileyi”" uygulayalım, tabiat (nature) ihtiva etmek için onu bozan ve kirleten çileyi değil, fakat tabiatı denetleyerek, yumuşatarak, onu kırmayan, ama aksine ona tamlığını, ahenkli gelişmesini sağlayan çileyi uygulayalım. Ona her kötüye kullanımı yasaklamak, onu gevşemekten ve uyuşuklukla bozulmaktan engellemek, onu her çalışmaya mümkün olan en elverişli hale getirir, bir bilgenin kendi öz bedenini incelemesi böyledir.

c- İnsanın Kendi Öz Zekası İle İlgili Ödevler: Bu görevler iki kelimeyi içine alır: Kendini yetiştirmek ve kendini olgunlaştırmak. Kendini yetiştir- 
mek, kendini bilgilerle donatmak, çok çok üretebilmek amacıyla kendini zenginleştirmek. Her şeyi yeniden bilmek, eylem alanımızın bir büyümesi değil midir? - Olgunlaşmak, iyi yargılamaya çalışmaktır, her şeyi kendi doğru pahasında (prix) değerlendiren kesinliği, belirginliği, dengeyi elde etmektir. Sabır, tedbir, alçak gönüllülük, kesin doğruluk, her zihnin (esprit) elde etmeye ve geliştirmeye mecbur olduğu erdemlerdir. Bunların meyveleri "sağduyu" diye isimlendirilir.

d- İnsanın Kendi Özel Karakteri İle İlgili Ödevler: Bu, her insanın geliştirmek mecburiyetinde olduğu kendi karakteridir. Hiçbir kimse yetkin olarak doğmuyor. En iyi kimsenin bile, düzeltmesi gerektiği küçük kusurları, doldurması gerektiği boşlukları, belki de kökünü kazıması gerektiği günahları vardır. Çalışmamızın konusu sadece bizim çevremiz değildir; o yine bizzat kendimizdir. Doğuşumuzla bizzat kendimize verilmiş aşısız bir fidanız: Ondan, kuvvetli ve iyi meyveler yüklü ağaç yapmaya mecburuz. Onu erdemle süsleyelim. Bizzat kendimizden şaheserler yapalım.

Bununla beraber, aptalca bizzat kendimizden hoşlanmaya gitmeyelim. Ayrıca, asla erişemeyeceğimiz olgunluk, hoşa giden bu hayranlık tutumu, hayatımızı verimsizleştirecek, ve ruhumuzun bakışını amacından ayıracaktır. Olgunluğumuzu araştırarak, bizi, bizimle yapılan iyiliğin başarısından daha az düşünelim.

O halde bakışlarımızı alçak gönüllülükle, iyi ile kötünün karışmış olduğu karakterimiz üzerinde toplayalım. Sabırlı, uyanık ve dikkatli bir çaba ile kendimizi tanımayı, karşılıklı birbirine katlanmayı, yola gelmeyi öğrenelim.

e- İnsanın Kendi Öz Şerefiyle İlgili Ödevler: Bu, her birimiz için hayvan veya eşya seviyesine inerek, insan mevkisinden düşmemenin görevidir. $\mathrm{O}$ halde insan, bizzat kendine utanç veren her fiil ve arzuyu, taşıyıcısı olduğu insanlığa bir hakaret olarak düşünecektir. Beden ve ruh, ilâhi bir eser olarak onurlarını koruyacaklardır. Ve insan, onu alçaltmaya teşebbüs eden herkese karşı insan şahsının saygınlığını, kendine olduğu gibi diğerlerine karşı da koruduğu için kendine tamamen saygı gösterttirecektir.

\section{B- BAŞKASINA KARŞI ÖDEVLERIMIZ}

Başkası Kimdir? Başkası, bizzat bir başka kendimizdir, veya (özellikle kelime kolektif bir anlama sahip olduğu için) daha ziyade, bunlar "benzerle- 
rimiz" dirler. Fakat bu benzerlik kesin olarak neden ibarettir? O esas olarak ırkîdir, ve onun gerçek ismi kardeşlik olacaktır. Benzerlik menşe', yaratılış (nature), alınyazısı ortaklığıdır. Elle uğraşılmış parçaları, insan cinsinin soy kütüğünü kurma yeteneğine sahip olmamıza rağmen, onların tek ve aynı kaynaktan türediğini düşünüyoruz. Zihinsel ve ahlâkî aktivite yetenekliliğimizi kendinde bulduğumuz tamamen canlı insandır.

Kendi yakınımızı da başkası olarak isimlendiriyoruz. Fakat böyle bir durumda yine terim açıklanmalıdır. Bütün insanlar yakından bize benzemezler. Orada "yakınlarımız" diye isimlendirdiklerimiz vardır; bunlar ailemizin üyeleridir; onların bizimle olan yakınlık bağlarını biliyoruz. Diğerleri ile yakınlık daha uzaktır: Bunlar milletimizin üyeleridirler: Onların bizim cinsten olduklarını kapalı bir şekilde biliyoruz. Yakınlıkları oldukça uzak, oldukça doğrulanamaz olanlar vardır ki onları yabancı olarak nitelendiriyoruz. Bunlar komşu cinslerin veya uzak ülkelerin insanlarıdırlar. "Proximi, propinqui, externi”, içtenlikle (intimité) üç dereceye işaret ederler. Dayanışma az göründüğü ölçüde, zorunluluklar daha gevşek gibi görünürler. Her şey eşit olunca insan kendini, vatandaşlarından ve yabancılardan daha fazla oğullarına adar.

O halde eşitlik kavramını kesinleştirmek gerekir. İnsanlar arasındaki eşitlik, olgu değil bir hukuk eşitliğidir. Yaşı, cinsiyeti, ırkı, yetenekleri ne olursa olsun, bütün diğerleriyle aynı kadere çağrılan her insanî varlık, diğerleri kadar "kutsal"dır, ve onlara köleleştirilemez. - Fakat bu sıra eşitliğini, yeteneklilik benzeşimine dönüştürmek tehlikeli bir yanılmadır. İnsanlar ne güçte, ne zekâda, ne de ahlâkî değerde birbirine eşittirler. Ve aynı şekilde onlar atandıkları görevlerde de büyük farklılık gösterirler. - Toplumsal ahengin dayandığı yer, kesin olarak bu farklılıktır. Hukukta eşitler, iki eş, farklı ve tamamlayıcı görevlere daha az sahip değildirler. Hukukta eşitler, büyük baba ile küçük torun, tecrübenin cehalete olduğu gibi biri diğerine daha az zit olmazlar. Eşit saygınlığın dogması, ihtiyaçların, görevlerin ve durumların aykırılığını unutturmayı gerektirmez.

"Başkasına" karşı görevimizi bilmek için, kendimizin "bizzat bir başkası”" olduğumuzu bilmek yetmiyor; bize, onun hangi durumda bize bağlı olarak var olduğunu, onun bireysel olarak var olduğu şeyi de bilmek gerekiyor. - Bizim çalışmamız böylece ikiye bölünmüş bulunuyor. İnsanın, hangisi olursa olsun her insana karşı mecbur olduğu (genel ödevleri); ve bazı (kısmî görevlere) 
bağlı olarak kendi özel durumundan doğan mecburiyetlerin hangileri olduklarını incelemeye mecbur olacağız.

\section{BAŞKASINA KARŞI GENEL ÖDEVLER}

Onlar iki temel ilkede özetlenir: Dört esas hakkın (hayat, mülkiyet, hürriyet, saadet) saygisı olan adalet ve iyilikseverlik, sayısız formlarda yardım. Bu ödevlerden her biri bazı açıklık ister.

1- Hayata ve Başkasının Bedenine Saygı: Başkasının saygınlığı bize onu öldürmeyi, onu sakatlamayı, onu yaralamayı, onun vücudunu kötü kullanmayı yasaklar. - Modern şuur, adam öldürmeye izin veren üç hali artık tanımıyor: Öldürmenin, daha kıymetli olarak değerlendirilmiş bazı hayatları kurtarmanın tek vasıtası gibi göründüğü durumlar: Meşru müdafaa, haklı savaş, ölüm cezas1. Fakat bu noktada hangi tuhaf değişiklik geleneklerin tarihini temsil eder! Falan vahşi kabileler, düşmanlarıyla, geyik gibi beslenirler; diğer falanları, oğulların görevinin, ruhlarını toplamak ve çökmüşlüğün utancından onları kurtarmak için yaşlı ebeveynlerini (parenti) yemek olduğuna inandılar; diğerleri yeni doğmuş zayıf veya fazladan bebelerin yok edilmesini zorunlu gördüler veya hoş gördüler; "halk kurtuluşunun", bakılacak yararsız kimseleri, delileri veya vebalıları yok etmeye müsaade ettiği zaman çok eski değildir.

Bedenle ilgili kötü muamelelere gelince, bütün artık onlar müeyyide olarak kabul edilmiyorlar: Haylaz çocuğa tokat, yol kesici hayduda dayak... Fakat (istisani olan) bu düzeltmeler asla kutsal şeyleri küçümseme olmamalıdır. Cezanın uygulandığı caninin (malfaiteur) vücudu bile saygı hakkına sahiptir. İnsan varl1ğının, hiçbir şeyin kirletmesine izin verilemeyen bir edebi (pudeur) vardır.

2- Mülkiyetin Saygısı: Hiçbir insan beslenmeksizin, giyinmeksizin, barınmaksızın varlığını devam ettiremez. Hayatının şartı olan şeyin kullanımını bir kimseye vermemek, onun yaşama hakkını reddetmek anlamına gelecektir. Bütünüyle insan cinsi böylece kendinin altında var olan varlıklara hakim olmanın bir çeşidini uygular; Onlar kullanımına aittirler; ve her birey, eğer bu ortak maldan (şu veya bu form altında), diğerleri tarafından tanınmış ve saygı gösterilmiş küçük bir paya sahipse ancak yaşayabilir. Orada, onun özel bir alanı, kendi "mülkiyet"i, - kendi şahsının bir çeşit uzanması vardır. Çalma, hile, yağma böylece onu kendi mülklerine ulaştırırlar (atteindre). $\mathrm{O}$ halde mülkiyet, ilk temel olarak insan şahsının saygınlığına sahiptir. Şahsın dokunulamaz karakteri, adeta kendi hayatının aletleri olan şeylere kadar yayılır. 
Fakat toplum az sonra, mülkiyet hakkında, doğrulayıcı ve sınırlayıcı ikinci ilkeyi zorla kabul ettirir: Çalışma. Yaşamak zorunlu olarak tüketmek, ve bundan dolayı ortak mülkü azaltmaktır. Eğer hiç kimse üretmiyorsa rezervler çabuk bitecektir. O halde herkes kendi kaçınılmaz harcamasını, katkıda bulunucu bir üretimle denkleştirmekten sorumludur: Çalışma bir adalet görevidir. Bununla insan, kendi özel emeğinin meyvesi olan şeyi tüketiyor gibidir. İnsan, geçim payını, bizzat kendine onu temin ederek hak eder: $\mathrm{O}$ ekmeğini kazanır.

Mülkiyet hakkının bu iki temeli birbirini tamamlayıcıdırlar; ve adaleti tehlikeye sokmaksızın ikiden biri inkar edilemez. Birinciyi kaldırmak, üretim halinde olmayan herhangi birine, sakata, hastaya besini vermemektir. İkinciyi kaldırmak, diğerlerine şöyle söyleyen tembelin asalaklığını teşvik etmektir: "Ben bir insan değerine sahibim; beni besleyiniz."

İnsanın hakimiyeti meşru olarak neyin üzerine uygulanır? İnsanın kendisi hariç, her dünyasal gerçeklik üzerine uygulanır. Hiçbir kimse, başkasını kendi "eşyası" olarak düşünemez. Çocuk, babasının mülkiyeti değildir; hanım kocasının mülkü değildir; yenilen kimse yenenin mülkü değildir; borçlu kendi alacaklısının mülkü değildir. - Modern insan oraya, şahsî keşiflerini, aynı zamanda kendi icadı ve ekmek parası olan (edebî mülkiyeti, icadın beratnamesini) ilave ediyor.

Fakat istisnaî olarak bireye ayrılmış sahanın sınırlar ihtiva ettiği çok açıktır. Hiçbir kimse şunu söyleme hakkına sahip değildir: "Dünya bana aittir", - sadece emeğiyle üretilmiş olan insanın kendine aittir. Bireyin (kendi hayatına kastetmeksizin ihlâl edilemeyen) tam (strict) hakk1, kendi varlığını sürdürmek için gerekli olan şeydir. Fazlayı kendi çalışmasıyla elinde tuttuğu zaman insan ondan meşru olarak yararlanır, fakat, çabasına rağmen gereken şeyden yoksun olduğu zaman da insan onu bırakmak mecburiyetindedir. Haksız bir sefalet önünde benim fazlalığım, hakkım olmaktan çıkar. - O halde herkesin mülkiyeti çift sınıra sahiptir: Başkalarının mülkiyeti, ve onların meşru ve öz ihtiyaçları.

Nihayet birey hangi kullanımla kendine özgü mülk edinebilir? Bu mülk üzerinde onun hakkı mutlak mıdır? Hayır. Onlar diğerleri için bir çare olacaklarken Onları yok etmek, zevki için onları harap etmek, bir hatadır, zira bu, insanî sermayeyi yararsız bir şekilde fakirleştirmektir. Şüphesiz mülkte, yok etmeksizin kullanılamayan (harcanabilir) mallar vardır: Yediğimiz meyveler gibi. Onlar hakkında görevimiz, onları israf etmemekle yetinmektir. Fakat 
mülkte, zorunlu olarak var olmayan veya kullanımla aracısız olarak yok edilen, ve zenginliğin kalıcı kaynakları olabilen hususlar vardır. Bunları, asla kurutmamakla sorumluyuz. O halde onların bize ait oldukları bahanesiyle, egoist bir şekilde "benden sonra tufan olsun" diyerek, ormanlarımızı yararsız bir şekilde kesmeyeceğiz, evlerimizi temelinden yıkmayacağız, mobilyalarımızı yakmayacağız. - Taşınmaz mülkler, takip eden nesillere aittir: Bu nesillerden her biri, sırasıyla, ondan yararlanma hakkına sahiptir.

Her mülkiyet iyi bakılmış ve değerlendirilmiş olacaktır. Ortak zenginlik, her halde ancak herkesin zenginliğiyle gerçekleşir. Toplumun kendisi, bir yeteneksizin israfindan aile servetini korumak için "adlî konseyi" kurarak, ve bazen de, terk edilmiş verimsiz toprakların zilyetlerini kamulaştırmayla tehdit ederek onu içine aldı (comprendre).

3- Hürriyetin Saygısı: Söylediğimiz gibi hiç kimse başkasını kendi mülkiyeti gibi düşünemez. O halde kölelik en üstün haksızlıktır: İnsanı kendi şahıs titrinden yoksun bırakma, eşyaya karşı onun alçaltılmasıdır. - Bununla beraber kölelik, insan neslinin hesaplanamaz arkadan gelenleri boyunca, evrensel ve tartışılamaz kuruluş oldu. Galip ilkel toplum yenilmiş düşmanları ne yapmalı? İlkel toplumun hoş gördüğü kimse onun kölesi haline geliyordu: Vahşî hayat karşıllı̆ında, köle, bundan böyle kendi fatihine hareketli olarak (de meuble) hizmet etmeye razı olur (ve bazen de onu ister). Alacaklı aciz borçlusunu ne yapmalı? Malını alamayan kimse, şahsı ele geçirecek ve onunla yetinecektir. - Ve böyle bir çözüm o zamanın vicdanlarını oldukça az sars1yordu, savaşın mutsuzluğu ve işlerinin başarısızlığı köleler haline dönüşenler orada daha ziyade alın yazısına yüklenilebilen bir mutsuzluğu, insanların adaletsizliğini görüyorlardı. - Fakat insan, insanın bağımsızlı̆̆ına saygı göstermeyi yavaş yavaş öğrendi; ve bugünkü kölelik teorik olarak bütün milletlerde bertaraf edilmiştir.

Gerçeği söylemek gerekirse insan efendi olarak yalnızca Allah'a sahiptir. Bizzat kendinin iyiliği için kendi hürriyeti içte tutulmuş olmalıdır (eğitim çocuğu ebeveynlerine boyun eğdirir, bir milletin iyi düzeni vatandaşları tüzüklere boyun eğdirir...); fakat bunlar orada geçici ve ikinci derecede vardırlar; davranışından sorumlu birey bizzat kendi başına buyruktur. Hiçbir kimse onun adına isteme hakkına, ne de onun insani etkinliğini engelleme hakkına sahiptir. Onun düşünme ve eylem teşebbüsünü yasaklamak, onun şahsiyetini 
hiç kabul etmemektir. - Kötüye kullanılmadıkça herkesin hürriyetine saygı gösterilmelidir.

4- Başkasının Şerefine ve Değerine Saygı: İnsanın zenginliği sadece bir beden, mülk ve bağımsızlıktan ibaret değildir; o, saygı gösterilmiş olması gereken mutluluğunu ve ahlâkî değerini de ihtiva eder. Başkasını hor görerek inceleme, onunla alay etmek, onu maskaralık objesi etmek, - veya sosyal hayatının esas şartı olan ve hak sahibi olduğu güven ve düşünceyi, kara çalma veya alay etmeyle ondan almak, hakaret etmek değil midir?

Bilhassa onu kötülüğe sürükleyerek, değerden düşürmek, ahlâkî olarak ona zarar vermek değil midir? Onu bozmak, onu en kıymetli hazinesinden çıkarmaktır. Skandal, kötü nasihatler, gerçek suikastlar geleceğinin aksini oluşturur.

Genel Yardımseverlik Ödevi: Hangisi olursa olsun, bütün insanlara şunları borçluyuz:

1- Fizikî 1stırabın hafifletilmesi ve ahlâkî tesellî,

2- Maddî yardım ve nasihat,

3- İyilikte örnek ve cesaretlendirme,

4- Bilimin ve gerçeğin iletişimi,

5- Yükselten ve ahlâkî enerjiyi yeniden canlandıran af.

\section{Başkasına Karşı Özel Görevler}

Onları iki ana maddeye bölüştüreceğiz: Aileden doğanlar, - toplumdan doğanlar.

\section{I- AİLE İLE İLGİLI ÖDEVLER}

Soyumuzun içinde kaybolduğu anlaşılmazlık, insan ailesinin en eski formunu bize gizliyor. Burada her tasdik, sadece bir sistemle bilinçsizce ilham edilmiş olabiliyor. Ayrıca burada ahlâktan daha ziyade bir tarih problemi vardır.

İlk başlangıçların hangisi olursa olsun aile organizasyonun zamanla değiştiği ve bugün hâlâ onun farklı tipler ihtiva ettiği açıktır. Çok karılılık, çok kocalılık, tek evlilik, geçici anlaşma..., aşağ yukarı cinsel birleşmenin bütün formları var oldular veya halen var oluyorlar. Belki de bütün farklılıkların temel nedeni, falan veya filan topluma özgü olarak kalan veya var olan hayatın maddî şartlarında bulunabilecektir. Her ne olursa olsun, bütün cinslerin ilerlemeye doğru geliştiği eşlerle ilgili birliğin çözülmezliği ve tek evliliğe doğru gidildiği açıktır. O halde inceleyeceğimiz ödevler ailenin bu tipinde vardır. 
Öncelikle şu temel soruyu soralım: Bir aile kurmak ödev midir? Üretim içgüdüsü insanlar üzerinde güç sahibi oldukça ve kendi öz ırkına tapma (culte), bazı toplumlar üzerinde eyleme sahip oldukça böyle bir sorunun sorulması gerekmez gibi görünüyor. Bununla beraber, böyle bir sorunun sorulması kaçınılmazdır, mademki yasalar (législations) evlenmeyi kaydediyor, ve dikkate değer insan kıyımından hemen sonra bazı siteler, hayatta kalanlara ikinci bir eş almayı emrettiler.

Fakat böyle bir ilkeyi (précepte) ahlâkî olarak neye dayandırmak gerekir? İnsan şahsına hiçbir değer vermeyen veya hayatın bir kötülük olduğuna kesin olarak karar veren insan, anlamsız ve sefil bir varoluşu devam ettirmeye mecbur olduğuna açık bir şekilde inanmayabilir. Sadece, insanın değerine ve onun alın yazısının yararına iman, bir çocuğun dünyaya getirilmesini ahlâkî bir fiil olarak gösterebilir. Hayat insan için bir iyilik olduğuna, ve İnsanlığın tümüne ayrılmış kutsal çaba, bizden sonra da işçiler istediğine göre, o bir ödevdir. İnsanî gücü (sève) ayaküstü kurutmak kendi ırkımıza karşı bir hatadır. Keyfi bekârlık ayıp (coupable) bir egoizmdir. Bir aile kurmaktan sadece, yeterli bir canlılı̆̆1 aktaramayan hasta, veya ailevî mecburiyetleri, herkes için kutsal olan bir göreve engel olan adam, bağışık tutulur. Bunun için toplum, kendi sürekliliğiyle ilgilenir, iğdişleştirme ve çocuk düşürme cinayetlerini ciddi olarak cezalandırır.

O halde insan bir soya sahip olacaktır: İnsan, kaynaklar ve hanımın güçleri müsaade edeceği kadar çocuk yetiştirecektir. $\mathrm{O}$, kendi aile ocağını tek bir oğlan veya kendi düşüncesine göre mirastan yararlanma hakkına sahip olacak olan bir çift çocukla yetinmeyi amaçlamayacaktır. Yanlış hesap: Hastalıklar, savaşlar, her çeşitten kazalar, toplumun yoğunluğunun varlığını devam ettirmesi için çok sayıda aile merkezleri isterler. Bir aile kurmak, hayatlarını kendi başlarına kazanmak ve varoluşun asıl risklerine meydan okumak mecburiyetinde kalacak oğlan çocukları üretmektir.

Fakat kadının saygınlığı, cinsler birliğinin, şiddet olgusu veya bir pazar objesi olmamasını ister; ve çocuğun eğitimi iki ebeveynin kalıcı işbirliğini ister. Evliliğin kurulmasının temeli böyledir.

Tam formu altında evlilik, bir hayat anlaşmasıdır. - Sözleşme olarak evlilik, iki tarafın hür rızasını ihtiva eder. Böylece, evlenme çağındaki çocukların ebeveynleri tarafindan satışı ve zorla kaçırılması ölüme mahkum edilmiş bulunur. Hiç kimse onların kişiliklerini kendine ait bir eşya gibi düzenleyemez. - İkinci 
olarak bu sözleşme, birbirine bağlı ikilinin ahlâkî eşitliğine saygı göstermek mecburiyetindedir: Biri diğerinin eşyası haline gelemez. Evlilik bir seviyede onlar arasındaki bir ortaklıktır. Modern şuur, tabakasındaki veya yabancıdaki hanım (épouse) sırasının reddedilmesini artık hoş görmüyor.

$\mathrm{Bu}$ sözleşme ile şunlar amaçlanmaktadır. Çocukların dünyaya getirilişi ve ortak hayatla getirilmiş olan karşılıklı yardım. O halde, isteyerek kısır evlilik ayıptır. O, ilk amacinı yerine getirmiyor.

Ve bu sözleşmenin şartları hangileridir? İki eş, sadakat ve yardımla birbirlerine sayg1lı olmak mecburiyetindedirler. Duygulanıma gelince o, bir davranış kuralının (précepte) objesi olamaz; duygu kendi kendine hakim olmaz. Fakat duygulanım (affection) burada o kadar zorunludur ki onun sadece sevilen ve sevilmeyi bilen bir şahsı birleştirdiği söylenebilir; sadece bir çabanın gerçekleşmesi olarak anlaşılmış eşlerle ilgili bir hayat, sonuna kadar destekleyememe tehlikesiyle karşı karşıya bulunulan bir görevdir. Çocuklarını baş göz ettikleri zaman karşılıklı sevgiyi hiç hesaba katmamak, ebeveynlere ait tedbirsizlik olacaktır.

Aile bir toplumdur, - hem de toplumların en "tabisidir", - ve özet olarak aile her insanî sitenin çekirdeğidir. Aile, otoriteye ve görevlerin aşamasına (subordination) önceden sahiptir. Söylediğimiz gibi iki eş, saygınlık bakımından kesin olarak eşittirler: İnsanî şahsiyet kadında erkektekinden daha az değildir. Fakat onların işbirliği, birbirini tamamlayan karşılıklı görevler bağlılığını ister. Anneliğin, emzirmenin, çocuk tarafından istenilen en küçük titizliklerin engelleri bayanı, onu koruma ve ona hayatını kazanma görevini yüklenen kocanın fizikî astlığı haline koyuyor. O zaman ailenin genel yönetimi babaya düşer, evin (foyer) sorumluluğu (soin) ise annenin payıdır. Bu, anlaşmadan (entente) daha az bağımlılıktır: İki varlık yalnızca bir yapar.

İki ebeveynin tam birliği bozulmazdır. Onların ayrılmaları, özellikle çocuğu, ilgilendiren yönüyle, çaresi bulunmaz bir yıkımdır. Ona izin vermek için son derece ciddî örnekler gerekir. Bu, eşler için kendilerinin kaçınılmaz noksanlıklarını karşılıklı olarak taşımak bakımından bir ödevdir. Bunun içindir ki aşksız evlenmenin sakınımsızlık (imprudent) olduğu söylenir, biz aşkın, faziletin yerini tutamadığını ilave ediyoruz, silinip gitmelerini, yorgunluğunu önceden görmek gerekir ve o halde ne olursa olsun ödevini yapmaya hazır hale gelmeden ve evlenilecek şahsın aynı azimde olması temin edilmeksizin evlenilmeyecektir. 
Çocuğa gelince kuşkusuz ona hayat verenler onu beslemek, korumak, yetiştirmek ve eğitmek mecburiyetindedirler. Fakat ebeveynler onu, ne kendilerinin ayrılmaz arkadaşları veya oyuncakları olmak mecburiyetindeymiş gibi, ne de onu egoist kılacak bir şekilde yetiştirmek isteyeceklerdir. Onlar onu hayat için silahlandıracaklardır, kendi öz evini (foyer) kendi başına kurmak için kendi kendine yetmek haline koymak için - çocuk ebeveynlerin "mülkü” olmayıp onların tabiî koruma hakkına (kendi hakları ve görevleri ile) sahip oldukları bir insan şahsıdır ve onlar, ögüt ve örneğin dışında, daima canlı bir sadakat isteyen, vücudun, zihnin ve karakterin tam oluşmasından sorumludurlar.

Buna karşıllk, çocuk ebeveynlerine şükran, sayg1, itaat ve, gerektiğinde her formu altında yardım borçludur.

Bireyden başlayarak, en kutsal görevler aile ile ilgili olanlardır. Yakınlara karşı cinayetler (anasını ya da babasını öldüren, kardeş katili) en kötü olarak reddedilmişlerdir, bu cinayetler "yabancıya" karşı gerçekleştirmiş cinayetlerden "tabiata daha zıt"tırlar.

Aile nerede bitiyor? Mademki bütün insanlarda aynı kan akıyor onların sınırları keyfidir. İnsanlık tümüyle bir ailedir. Fakat, gerçekten, herkes için kendi ailesini oluşturan grup sadece, birbirini takip eden üç kuşağın (dedeleri, ebeveynleri, çocukları) soyu, ve bu üç grubun ihtiva ettiği yakın (collectérales) ilişkileri kapsar.

Fakat diğer taraftan aile sadece etnik bir grup değildir; o, aynı zamanda ekonomik bir grup, toplumun bir başlangıcıdır. Zengin aile (foyer) fakir aileyi kendine çeker. Geçim kapısı "evle ilgili" hizmet olan çalışanlar birliği, antik "familia" böyle oluşur. Uzun zamandan beri istisnaî form olan köleliğin hoş görülmeyeceği çok açıktır. "Hizmet”, adaletli bir ücretin çalışma karşılığı olarak verildiği, hür olarak razı olunmuş bir sözleşmenin objesidir. Fakat bu çalışmanın tamamen özel cinsi, görevli ile işverenin bir birine karıştırıldığ ilişki, adalet görevine, ilgi (egards) mecburiyetlerini, eğitim endişesini, sayg1y1 ve korumayı ilave ediyor.

\section{II- TOPLUMSAL ÖDEVLER}

Toplum: Aileninkiler gibi insan toplumunun kaynakları da bizim gözümüzden kaçıyor. En eski izlerin bize açıkladığı formlar hiçbir şekilde ilkel görünmezler. Başlangıçların her yeniden oluş biçimi tasarlama asla sadece 
hayalî olmayacaktır, - şüphesiz, az veya çok gerçeğe yakın, fakat her zaman keyfî̀ ve doğrulanamaz olacaktır. Ailenin sebatlı bir gelişmesinden kaynaklanan toplumun, aynı bir soyun sadece devamlı bir birliği olduğunu söyleyecek miyiz? Veya toplum, insanın dışındaki, tehlikeler ve ortak bir ihtiyaçlar karş1sında benzer varlıkları toplayan dayanışmanın gizli duygusundan doğmamış mıdır? $\mathrm{O}$, muhtemelen daima birlikte hareket eden bu iki nedenin ürünüdür. Ne olursa olsun, toplum saf bir yapmacık değil, canlı zorunlulukların bir ürünüdür. İnsan sitesi, arı kovanı ve karınca yuvası kadar “tabî̂"dir.

Fakat insanî olan her şey gibi toplumda, ne tamamıyla kendiliğinden, ne de mutlak olarak hareketsiz bir şey değildir. Aynı zamanda kaçınılmazken, insanlar arası anlaşma kısmen iradîdir; aynı zamanda uyulması zorunlu iken o, tercih edilir, razı olunur, tartışı1ır. O halde gerçek şu ki insan toplumu kısmî olarak bir karşı1ıklı hizmet sözleşmesine dayanır, - bu sözleşme, başlangıçta aniden formule edilmiş, ve kapalı bir şekilde şuurlu her gün daha açık ve daha kesin olan bir sözleşmedir.

$\mathrm{Bu}$ aile arası ortaklaşmada amaç nedir? Müşterek koruyuculuk - Ve bu sözleşmenin şartları hangileridir? Karşılıklı hizmet ve her verimli işbirliğinin şartı olan disiplin.

Fakat toplum, sadece bireylerin hayat biçimi değildir, ortaklaşa (collectif) biçim tek başına yaşama biçiminin karşıtı olur; her bireyin nazarında toplum, birbirine benzeyenlerin anonim toplanması, veya daha ziyade, hakları ve başkasının görevlerini adeta merkezleştiren bir çeşit ortaklaşa varlıktır. Bu kümelenmenin oluşumu, bireyin artık sadece sayısız kardeşlerinin her birine karşı özel ödevlere sahip olmasını değil, fakat toplumda, - ilkin şehir, sonra millet, ve daha sonra İnsanlık halindeki toplum halinde şahıslaştırılmış bütünlüklerine (ensemble) karşı kendini zorunlu hissetmesini gerçekleştirir.

Toplum denen bu ortaklaşa varlığın realitesi kesin olarak nedir? Orada, onu oluşturanlara ilave edilen yeni bir varlık tabiî olarak görmeyeceğiz. O, tabiî olarak onların bütünü ve organizasyonudur. Onun şahsı sadece onların toplamıdır; onların hakları ve ödevleri, sadece onların toplamıdır. Toplumu biricik kutsal Gerçeklik, bireyleri sadece türemiş veya hizmetçiler olan şahıs yapmak, soyutlamaya aldanmaktır. Kutsal olan şey, ilkin bizim her birimizde, ve bizim her birimizin karşısında, var olsun veya ortaklaşa biçim altında birleştirilmemiş olsun, insan şahsiyetidir. Gerçek, ferttir; ve toplum, ciddî olarak 
konuşmak gerekirse, sadece hayatlarının az veya çok ahenginin herkese ait olmasıdır. Ortaklık insanlar için yapılmıştır ve insanlar ortaklık için değildirler.

Toplumun kendisini, onun yarattığı, ve onu destekleyen güçlü çatı (ossature) ile karıştırmayacağız: kuruluşlar, diller, abideler...

Fakat Toplumun karşısında birey az bir şeydir! Toplum çokluk, hayatta kalma, gelenektir. Hatta, bireyin ecdadından kendine nakledilmiş insan şartının büyüklügünü hissettiği yer özellikle toplumun arasıdır. Böylece her millet kendi kaynağını ülküselleştirir ve aksi halde kendini evlatlar olarak, en azından başlangıçta, kendini organize eden Medeniyetle kendini donatmış olan bir tanrının imtiyazlı bir ailesi olarak düşünür. Tarih Onu kanıtlıyor: Bir tanrıdan geldiğine inanmış olan halk yoktur. Ve bu sadece yarım hatadır, çünkü insan, eğer kendinde Tanrı'dan bir şeyler varsa ancak kutsaldır.

Bir halkın kişileşmesi olarak düşünülmüş Toplumda, (gerçekte birbirinden ayrılmayan) iki şeyi inceleyeceğiz: Üyeleri arasında taksim edilmiş bir grubun otoritesi; ve yasaları tarafından ifade edilmiş, aktivitesinin disiplini.

Toplumsal Otorite: İnsan toplumu, kesin olarak aynı görevi gerçekleştiren, tamamen özdeş bireylerin bir araya gelmesi değildir; o ayırt edilmiş ve zorunlu olarak aşamalandırılmış bir vücuttur(corps). O, iki çeşit otoriteyi kendinde zorunlu olarak birleştirir: İlkin, (daha önce aileyi keyfî olarak yöneten otoriteyi) hiç bilmeyen gençler üzerinde tecrübe edilmiş olan eskilerin otoritesi ve aşağı yukarı her işbirliğinden kendiliğinden doğan otorite. Bir sandalın manevrası, bir avın başarısı bir emir ister. Her toplum, ayakta kalmak için, kendi yönetimini gerçekleştirir. Anarşi, anlaşmanın yıkımı, ve ortak haldeki her çalışmanın imkânsızlığı olacaktır.

Belki de hiçbir şey, şehir devletlerinin (cité) oluşmasından daha farklı ve daha kararsız değildir. Monarşi, oligarşi, aristokrasi, demokrasi... bütün yönetim biçimleri denenmiştir; ve onların her biri kullanımlarında tehlikelerini ve avantajlarını gösterdi. Ayrıca yönetim biçimi, ahlâktan daha ziyade yönetim işidir. Esas olan sosyal otoritenin kullanımıyla meşru olması, razı olunması, ve ona görevlerinin ve haklarının açık olarak belirtilmesidir.

Şehir devletinin yönetimine kim sahip olursa olsun ( ona miras yoluyla sahip olması, onu bizzat kendinin üstüne alması, onu seçimle alması) o gerçekten, vatandaşların vekilidir. O, kendini onların sahibi ve efendisi olarak değil, 
fakat onu yönetmekten sorumlu vasileri (curateur) olarak düşünmek mecburiyetindedir. O, onlar için vardır, ve onlar kendisi için değil. Kötüye kullanımı (abus) önlemek için, veya yetersizlikleri gidermek için sadece görünerek herkesin teşebbüsünü korumak, sosyal otoritenin rolü böyledir.

Karşılık olarak, vatandaş ona, anlayışı 1 bağ 111 k, meşru ve kendiliğinden işbirliği borçludur. Otorite zilyedinin arkasında, itaat ettiği ve hizmet ettiği kardeşlerinin bütünü vardır.

Sosyal Yasa: Sivil yasa, millî iradenin resmî ifadesidir. Hatta o, anlaşıldığ 1 ve monark (hükümdar) tarafından resmen ilan edildiği zaman bu, takdim edilmiş gibi olduğu zaman bir bireyin arzusu değildir, fakat ihtiyaçları nedeniyle Millet tarafindan istenilmiş ve verilmiş genel bir emirdir.

Onun kaynakları çeşitlidir. Başlangıçta (yaşını ve mucitlerini bilmeyen) genel gelenektir; sonra (nedeni ve imzalayanı bilinmeyen) emir; en sonra (metotlu derleme halinde sistemleştirme) yasa' dır.

Bu sosyal emrin kesin olarak değeri nedir? Ekseriya onun otoritesi ahlâkî olarak doğrulanmıştır, çünkü o gerçekten genel iyiliğe hizmet ediyor. Fakat yasa'nın tam olması gerekir. İlkin o ancak yarı kötüye kullanmalara çare bulmaya ulaşır, veya hatta onu başlatır; - Yine o, bir ihtiyaca cevap vermeyi b1raktığı için, ayak diremesiyle bir fazlalık ve bir engel haline geliyor; - nihayet o, ister hükümdar, ister yöneten kast, isterse milletin çoğunluğu adına olsun, otoritenin alenî kötüye kullanımını oluşturuyor. Gerçekten sayı, en adili meydana getirmiyor, o hakikati de kurmuyor. Eğer çoğunluk azınlığın soygununa karar verdiyse, böyle bir dürüst yasayı yargılayacak olan, "en büyüğün yararı hangisidir?" Tıpkı birey gibi çoğunluk da yanılabilir; ve adaletin erdemi, en büyük sayının payı olmaktan uzaktır.

Yasa koyucunun görevi, hiç kimseyi kutsallaştırmayarak herkesin iyiliğini temin etmektir. Çoğunluğun görüşü kıymetli bir delildir, fakat geriye partiler üstü şuuru, kendi dürüst insanî şuuruyla karşılaştırmak kalıyor.

Onun doğru bildiği Yasaya vatandaşın sakınımsız saygı göstermesi gerekir. Eksiklikle yargıladığı şeye o, disiplinle razı olur, fakat eksikliği ondan çıkarmaya cesaret eden onu düzeltmeye çalışır. Yasada açık olarak bir adaletsizlik (injüste) varsa ancak o zaman ondan kendini yoksun bırakmak ödevine sahip olunur. Fakat bu hal nadirdir; geniş bir tecrübe isteyen konularda kendine yargıç süsü vermek daha çok kendini beğenmişlik olacaktır. 
Devletin İşlevleri (fonctions) ve Ödevleri (devoir): Devlet, milletin yaşayan kişileşmesidir, dışarıda yabancılar karşısında ve içerde vatandaşın karş1sında milleti temsil eden şeydir.

Devlet, toplamı yönetim ve millî hayatın organlarının sistemi olan birçok "eyaletlere" dağıtılır.

O halde Devletin rolü nedir? Yönetim ve koruyuculuk görevidir, onlar da şunlardır: Yükümlülügüne sahip olduğu topluluğu (collectivité) korumak ve ona hizmet etmek. Onun temel işlevleri şöyle gruplandırılabilecektir: - Dışarıda, yabancılar yanında millî menfaati savunmak; - içeride, düzeni devam ettirmek, yasaları kesin olarak yayınlamak, adaleti hakim kılmak, ortak tehlikeleri savmak, mutsuzlara yardım etmek, genel ilerlemede her şeye yardım etmek.

Fakat Devlet, kendi müdahalesinin sınırlarını bilmek mecburiyetindedir. Onun rolü bireyi, bütün girişimleri tek başına yüklenen bazı politikacılar tarafından sürülen makinenin pasif ve anonim çarkı şartına indirgemek için, sorumluluklarından kurtarmak değildir. Her insan için ideal, kendi hürriyetinin akıllıca ve kibarca korunmuş olmasıdır, fakat (engelleme anlamına gelecek şekilde) onu, düşünmekten, cesaret etmekten ve istemekten bağışık tutan bir kitle tarafindan el konulması değil.

Milletlerarası Ödevler: - Millet bir aileler birliği olduğu gibi İnsanlık da, milletler birliğinden oluşmuştur (yapılmıştır). Fakat bu sonuncuların arasındaki bağlılık, aynı halkın aileler arasındakinden daha azdır. Kaynak (origine) ortaklığı artık kendini hissettirmiyor, karşılıklı olarak yabancı gibi niteleniliyor; ekseriya zıt görünen yararlar, yöndeş ve rakip olarak inceleniyor. Böylece menşe'lerinden (origines) beri belki de gizli düşmanlık halinde yan yana yaşayan halklar, daima kanlı bir savaşı patlatmaya hazırdırlar. İnsan gruplarının anlaşmak için meydana getirildiği ve vatandaşları kendi aralarında bağlayan zorunlulukların milletleri de kendi aralarında bağladığ 1 açıktır.

Gerçekten her millet, hak ve görevlerine sahip olan ortak bir şahıs oluşturur. Adalet, Devletlerarası ittifakları yönetecektir. Adalet özel antlaşmaları yönettiği gibi; ve komşusunun fakirliğine yardım etmeyi bireyden isteyen iyilikseverlik gibi, mutlu devlete de büyük felâketin çarptığı halka yardım etmesini emretmeyi gerektirir.

O halde açık olarak telaffuz edilmişliğine sahip olmaksızın halkların önceden hissettiği milletlerarası bir yasa vardır. Bireyler gibi, milletler de özel 
şuurlarına sahiptirler; hatta Milletler, onlar gibi cinayetlerine ve değerlerine sahiptirler; onlar zararlarının tamirine zorlanmışlardır... Kısacası milletlerin karşılıklı ilişkileri, sadece birinin sefaletini er veya geç herkesin sefaleti yapan ekonomik dayanışmayla değil, fakat daima gerçek kardeşlikten daha canlı bir duyguyla ilham edilen bir Allah'a bağlıdırlar.

Orada eşitsizlik kaçınılmazdır, fakat ahlâk köleliğe veya soyguna izin vermez. "Aşağı" ırklar geri bırakılmış, diğerlerinden daha az kayrılmışlardır: Bu ırklar ne dışlanırlar, ne de büyülenirler, fakat eğitilirler, korunurlar ve yardım edilirler. Artık köle birey olmadığı gibi, toprağa bağlı köle halkın var olması da gerekmez. Hiçbir ırk, kuvvetle, bir imparatorluğa girmeye zorlanamaz. Birey kendini düzenleme hakkına sahip olduğu için, komşu millet, yasa koyma başkaları için tehlikeli olmadıkça, hür olarak gerçekleştirilmiş yasa koymaya müdahale etmek hakkına sahip değildir.

Ayrıca, mademki o, bütün halkın işbirliğiyle ancak gerçekleşebilen bir ilerlemedir, onlardan her biri, tüm insanlığın hizmetinde kendi payına araştırma ve aydınlanma ileri sürecektir. Kötülükler ve çareler birlikte, ve somut uygulama ölçüleri de birlikte etüt edilmiş olacaktır.

Fakat, tamamen birleşerek ve ahenkleşerek milletler artık tek biçimli bir insanlıkta kaybolmaya mecbur olmuyor, ve aileler Millette erimeye, terk edilmeye mecbur olmuyor. Hayatın içinde kaynadığı ögeler budur. İşbirliği, erime (absorption) değildir; ve eğer uyum gelişmenin kaçınılmaz bir şekilde faktörü ise, değişiklik ve bireysel girişim de hâlâ (encore) vardırlar.

\section{III- HAYVANLARA KARŞI ÖDEVLER}

Eğer hayvan sadece bir nesne ise, onun üzerinde her hakka sahip olacağı. Fakat onun tabiatı bize nüfuz edilemez olarak kalmasına rağmen, onda nesne ile bizim aramızda aracı bir varlık görmekte kendimizi engelleyemiyoruz. O zaman taş bize duygulanımsız ve pasif gibi görünüyor, hayvan bize hissetme izlenimini veriyor, ve o, neşeye ve istıraba elverişlidir. Oysa bu, şuurumuzu uyarmaya yetiyor. Eğer evrensel mutluluğun işçileri olmaya davet ediliyorsak, ne olursa olsun, 1stırap üretmekte haklı olur muyuz? Hayır. Hayvana işkence etmekten hoşlanmak, oyunla onu harap etmek, kesin olarak onun Yaratıcısının isteklerine girmek değildir, ve bu bizzat kendi başına kötülügün yaratıcısı olmaktır. 
Şüphesiz, hayvanlarla bizim aramızda, insanlar arasında yer alan hak eşitliği yoktur; fakat mademki onlar aynı çamurdan yapılmışlar, ve onlar aynı Tanrı'nın eserleridir, öyle ise bütün canlılar arasında uzaktan bir yakınlık yok mudur? Bu unvanla, yaşayan her şeye yardım ve rahatlık vereceğiz.

Fakat iki olgu, bütün yaşayanlar arasındaki barışın cennete ait bu hayalini acayip bir biçimde kararttı.

Birincisi, dünya hayatının güncel yasasının yarış olduğudur. Ne kadar hayvan bize düşmandır! Her ne kadar biz onlar önünde silahsız olursak da, onlar bizim önümüzde silahsız olmazlar. Ne yapmak gerekir? Onları insanlara alıştırarak veya onları evcilleştirerek değiştirmek, şüphesiz arzu edilir olacaktır. Fakat bu başarı bize onlarla aramızda seçim yapmayı gerektiriyor; ve bizim "değerimiz" bizi, onlarınınkinin üzerine soylu bir biçimde götürüyor. $O$ halde ünlü zararlı hayvanların tahribi, insanı koruma bahanesiyle doğrulanmıştır. Hatta o zaman, bununla beraber yenilmiş hayvanlara yararsızca işkence yapmaktan utanç duyuyoruz, onun içgüdüsü takip edilince suçlu olarak incelenemeyecektir.

İkinci olgu, otçul ve etçil halde kurulmuş (construits) olmasıdır; bu, varlığımızı devam ettirdiğimiz canlıların asla zararına değildir. Bu hususta çekimser kalmamız yok olmak olacaktır. Yine burada nasıl yapmak gerekecek? Şüphesiz ideal, etiyle bizi beslemesi için hayvanın tabî̂ veya kaza ile ölmesini beklemek olacaktır. Belki de bir gün o vuku bulacak mıdır?... Her ne olursa olsun öyle görünüyor ki, hayatımız devam ettirmek için, hayvanı öldürmek, en azından ona hissedilmez ölümü vermemiz, ve onun kurban edilmesi saatine kadar onu sessiz bir varoluş yapmamız, bizim kusurumuzdur.

Bilhassa iş arkadaşı yaptığımız hayvanları unutmayalım: Tarlamızı işleyen öküzün mallarımızı koruyan, veya belki de hayatı kurtaran köpeğin yemini reddetmeyelim.

Fakat hayvanlar için kendi benzerlerimizden daha fazla saygıya göstererek, bir aşırılıktan diğerine gitmeyelim. Haklı olarak domuzlarını semirtmek için çocuklarını ekmekten yoksun bırakının cinayetini inceleyeceğiz. Hayvandan önce insana yardım edilmek mecburiyeti vardır. Bu iki özdeyişi uzlaştırmak gerekir: Her varlık kendi mevkiine (rang) göredir, her varlık kendi ihtiyaçlarına göredir.*

* Tercüme s.498'e kadar yapılmıştır. (çev. notu) 